\title{
Societal Accountability and Democratization in the Philippines
}

\author{
Aries A. Arugay \\ Aries A. Arugay is a former graduate student at the faculty of Political Science, \\ University of the Philippines, currently at the Department of Political Science in the \\ same university
}

ABSTRACT:The multifaceted interpretation of the 2001 People Power Revolt illustrated the skepticism with regard to the progress of democratization in the Philippines. However, it is also important to view it as an event that has put the issues of accountability to the fore. It examines the concept of "societal accountability" as a response to the problems faced by the legal-institutional mechanisms of accountability. It applies this in the resignation, impeachment, and ouster (RIO) campaign of the former President Joseph Estrada. It argues that societal accountability was exercised through three strategies: the legal process of impeachment, the utilization of media, and the mobilization of different civil society organizations through protest actions. The paper concludes by enumerating its implications on democratization in the Philippines.

\section{Introduction}

Since the First People Power Revolt in 1986, the Philippines has embarked on a process of "redemocratization". While it has passed the conventional "turn-over test" (Huntington, 1991) of the transfer of political power and has relatively remained politically stable, doubts continue to pervade the analysis of scholars and observers, particularly with regard to its prospects for democratic consolidation. There is a consensus that much leaves to be desired in terms of the maturity and efficacy of its democratic political institutions. It is not therefore contested that the Philippines suffers from severe "democracy deficits" on both the dimensions of institutions and politics required in a democracy.

The multifaceted interpretation of the second People Power Revolt on January 2001 illustrated the skepticism with regard to the progress of democratization in the Philippines. Some have heralded it as a triumph for democracy, indicating that without popular support, the legitimacy of any government is questionable (Doronila, 2001). However, most international observers have claimed that it was a "mob rule" in action and therefore a not so good indication of the overall condition of the country's democratic institutions and processes (Putzel, 2001; Burton, 2001; Spaeth, 2001).

While this paper believes that the event in 2001 displayed both the best and the worst of Philippine democracy, it takes a different position in the sense that it has put the issues of accountability and corruption to the fore. On the one hand, the resort to "extra-constitutional" means to oust an inept and corrupt president is a manifestation of the immaturity of Philippine political institutions to effectively exercise accountability - a principle inexorably linked to democracy. The aborted impeachment process is only the culmination of the severe deficits that exists between formal mechanisms of accountability and their ability to fulfill their mandate. On the other hand, it manifested the Filipino people's disgust and disappointment to a popularly elected president who committed grave acts of corruption and abuse of authority - a disease that has plagued the country for decades. 
In 1998, Joseph Ejercito Estrada, a politician who started as a movie actor, was elected the $13^{\text {th }}$ president of the Republic of the Philippines in a relatively overwhelming fashion, being able to get 40 percent of the national vote. Much of his electoral victory could be attributed to the support he received from the masa (masses), which constitutes to more than two-thirds of the population. Estrada electoral campaign slogan, Erap Para $\mathrm{Sa}$ Mahirap [Erap for the Poor] basically summarized his heavily populist political platform - a focus on the needs and issues that concerned the Filipino poor previously neglected by his predecessors. Despite being criticized for his ineptness, incompetence, and moral foundations, many gave him a chance to prove otherwise. A lot of people trusted him to genuinely contribute to the upliftment of the plight of millions living in poverty. However, not even halfway to his six-year term, Estrada was ousted through a peaceful revolt on the grounds of corruption and cronyism. This happened after the political institutions mandated to make Estrada accountable - the impeachment process - proved to be incapable to deliver on its mandate.

There seems to be consensus in the literature regarding the inability or failure of the democracies to address certain gaps and deficits in fostering more accountable democratic regimes (O'Donnell, 1994; Zakaria, 1997; Diamond, 2000). According to O'Donnell (1999), accountability has two dimensions: horizontal and vertical. The horizontal dimension is concerned with the existence of a system of checks and balances and with due process in government decisionmaking. It rests upon the assumption that government has the ability and willingness to restrain itself ("accountability from within"). However, the horizontal mechanisms of accountability in the form of the ombudsman, anti-corruption agencies and courts, legislative oversight committees, and others often do not possess sufficient independence to insulate themselves from undue political influence and the adequate resources to gather information and act effectively upon complaints.

There is also a vertical dimension that focuses on electoral mechanisms or other direct means ("accountability from above"). In any democracy, elections are the prime mechanism of ensuring accountability of political leaders to the citizens. However, even if one assumes that the electoral exercise is fairly free, clean, honest, and competitive (which in itself is already problematic in the Philippine context), there is still the danger of its efficacy as a vertical mechanism of accountability. Aside from the fact that it is a one shot deal held very often, it is not easy for individual citizens to coordinate the orientation of their votes. Moreover, there is the problem of inadequate information as citizens may not be able to sufficiently assess the performance of their political leaders or be aware of the relevant elections issues so important in making good choices at the polls (Stokes, 1999).

This paper shares the recognition that while these limitations on traditional accountability issues exist, a nascent form of generating accountability is emergent in democratizing countries such as the Philippines. It is grounded on a "growing recognition of the significant role of civil society and independent media in overseeing political authorities, exercising control over governments, and fostering democratic governance". Borrowing the concept of Smulovitz and Peruzzotti (2000), this paper wishes to focus on the notion of "societal accountability" as an appropriate response to the problems faced by the legal-institutional mechanisms of accountability as manifested in the campaign against President Estrada. It will discuss the issues put forward by societal actors and 
document their strategies from the call for his resignation until the cessation of the impeachment trial.

This paper argues that societal accountability to a great extent was exercised in this case since civil society and independent media organizations coordinated among themselves and effectively used a combination legal, mobilizational, and mediatic strategy. The legal strategy was exercised through the filing of the impeachment complaint thereby activating state institutions mandated to elicit accountability. The issues against Estrada were disseminated through massive and strategic mobilization of protest actions and other forms of collective action across the country organized by civil society groups and with the help of media exposés and the use of information and communications technology (ICT). This paper claims that the advent of societal accountability through the empowerment of civil society to participate in political processes has significant implications for the process of democratization in the Philippines. While societal accountability can never be alternatives for effective and properly working institutions of accountability, it can complement for their inadequacies and limitations.

This paper is divided into several sections. As a proper background, this paper will discuss the concept of societal accountability. It will then examine the issues raised against Estrada that caused the initiation of the actions of civil society groups which will also be identified. The paper will then document the various strategies of the relevant societal actors. Finally, it will explore the possible implications of societal accountability in the future of democratization in the Philippines.

"Accountability through Other Means": The Concept of Societal Accountability

One of the key distinctions of modern representative democracies from other types of regimes is the existence of a framework of legal and political institutions oriented to ensure the responsiveness and accountability of deputized agents. The idea that citizens are able to make certain demands on their political leaders and made them accountable for misbehavior could be considered as one of the incentives that democracy could provide. As democracy implies that those elected are to be the custodians of the people's authority, it requires the existence of institutions or mechanisms of accountability such that the authority given to those elected will not be abused or result in unresponsive governments. Most authors agree that the essence of the concept of accountability is how to regulate and control the authority given by the electorate to those who are elected (Schedler, 1999).

Conventional typologies on how to hold government accountable comprises the notions of political and legal accountability, wherein the former is grounded on the ability of citizens to elicit accountability through their vote (i.e. elections) and the latter into the ability of laws and institutional mechanisms to impose accountability (e.g. constitution, or checks and balances) (March and Olsen, 1995). However, a better way to conceptualize the means to impose accountability is through the use of "spatial metaphors". The concept of horizontal accountability refers to the operation of an "intra-state system of oversight oriented to control or punish actions or omissions by agents or agencies of the state that may be considered unlawful" (O’Donnell, 1999: 38). Vertical accountability implies the existence of an agent of control external to the government mainly via the electorate. Elections represent a "society-anchored agency of control, granting citizens the right to periodically punish or reward elected representatives with their vote" (Peruzzotti and Smulovitz, 2005: 6). Such 
a classification also stresses the direction of the accountability relationship as well as the arena where the accountability exchanges take place.

Peruzzotti and Smulovitz introduced a type of accountability that is neglected by current scholarship and has the potential to play a complementary role in fostering accountability in its legal and political aspects through compensating for the many built-in defects of traditional mechanisms. Societal accountability is defined as "a nonelectoral, yet vertical mechanism of control that rests on actions of a multiple array of citizen's associations and movements and on the media". Its agents monitor the actions of public officials, expose governmental wrongdoing, and can activate the operation of horizontal agencies. It employs both institutional (legal actions or claims before oversight/horizontal agencies) and non-institutional (social mobilizations and media exposés) means (Peruzzotti and Smulovitz, 2005: 9).

Societal accountability addresses some of the limitations of electoral and horizontal mechanisms. First, "unlike electoral mechanisms, societal accountability can be exercised between elections and does not depend upon fixed calendars. Second, it is activated 'on demand' and can be directed toward the control of single issues, policies, or functionaries. Third, it is not a reactive type of fostering accountability since it can oversee the performance of politicians while making policy. Fourth, unlike electoral and horizontal controls, actors that use societal mechanisms can perform watchdog functions without the need for special majorities or constitutional entitlements. Fifth, the sanctions of societal mechanisms may not be formal or mandatory, but they are symbolic through incurring reputational costs $(9-10)$. This is extremely significant in democracies since politicians rely on the votes of the electorate for their political survival.
There are three interrelated strategies employed by civil society in the exercise of societal accountability. First, there is the juridical or legal strategy. It entails the submission of societal actors of legal claims or of legally framed petitions to the courts or to other accountability agencies. Societal mechanisms are able to control since they can activate horizontal agencies and force them to intervene in disputes that the government may want to avoid or ignore. Working within the legal framework, societal demands for accountability can have the seal of legitimacy and therefore operate and respect democratic procedures and processes (Peruzzotti and Smulovitz, 2002: 9). Second, there is the mobilizational strategy. Control can be achieved if organized societal actors are able to call attention by exposing and denouncing perceived wrongdoings. Exposés bring issues to light in ways that the citizens can relate to, help put them on the public agenda and as a result, the number of matters for which public officials can be held responsible increases. The third is the media strategy which is the reliance on the potential of media to transmit the claims and issues to a wider audience increasing both the intensity and extensity of abuses of authority. Societal accountability requires visibility and media is the most important instrument to achieve this goal. It is argued that successful imposition of societal accountability depends upon the careful utilization and coordination of the three strategies. For example, "the media follows and reports about the organization and mobilization of civil society; civil society informs and is informed by media; and, at the same time, it activates legal actions and forces state institutions to take up once-neglected problems" (16-17).

Issues of Accountability: Estrada's Cronyism, Competence Deficit and Corruption 
Analysts have argued that Estrada was the president that would have had the best opportunity to be insulated from corruption. His popularity and charisma made it possible for him to win the presidency without too many political entanglements. His direct appeal to the masses added to his "winnability". Thus, Estrada represented the first opportunity to escape the vicious cycle of patronage and clientelism in Philippine politics. This implied that that Estrada could win without striking too many bargains and special arrangements (Laquian and Laquian, 2002).

While corruption maybe the overriding issue, Estrada was also accused of living an opulent and grandiose lifestyle, sometimes unfit for a public official elected to serve his country. And the means to materializing this lifestyle unfortunately were the use of public coffers like the untimely but costly renovation of the presidential yacht and residence (Doronila, 2001: 27-29). According to his cabinet members and friends, he is also known for having a "second shift" which refers to the nocturnal gatherings of Estrada and his well-known cronies infamously known as his "Midnight Cabinet", (not in the parliamentary sense) composed of his drinking and gambling mates. The members possessed awesome political leverage as they could influence policymaking through unsolicited advices to the President, while not being subjected to accountability, unlike official Cabinet members (Laquian and Laquian, 2002).

It is of complete irony that while Estrada distanced himself from traditional elite politicians or trapos and declared an explicit war on corruption, his short-lived administration was to be engulfed by a wave of corruption scandals. As indicated by the evidences introduced during the impeachment trial and those collected by the successor government to back the criminal charges of economic plunder, the deposed president allegedly amassed at least Php10 billion (US\$200 million) in cash and other assets. Transparency International (TI), an international anticorruption nongovernmental organization (NGO), placed him among the Top 10 Global Corrupt Leaders of all time.

The extent of corruption allegations against Estrada spanned from the systematic centralization of all illegal gambling "kickbacks" or "rents" (Hutchcroft, 1998) and exacting percentages from taxes to the manipulation of the country's banking and stock market to favor his kith and kin (de Dios, 2001; Pascual and Lim, 2001). The President also lied about his personal worth in his Statement of Assets and Liabilities (SAL), a compulsory document annually accomplished by all government officials. All of these were incorporated in the impeachment complaint filed against him by civil society organizations and opposition politicians.

Perhaps the "invincibility thesis" could partly explain why Estrada allegedly was able to commit these acts. Achieving a convincing victory against his opponents, the President believed he wielded tremendous power that became his leverage not only to implement controversial policies but allegedly to embark on a feast of abusing power and plundering the state treasury. $\mathrm{He}$ interpreted that his electoral victory was a "blank pass" that gave him free rein to do everything as he pleased, even if it meant being biased to friends or kin or jeopardizing the public good.

Moreover, Estrada was able to get away with being held accountable because he inherited a system where political institutions are weak and immature. $\mathrm{He}$ himself did not bother to contribute to strengthening these institutions; on the contrary, he even aggravated their condition (Abueva, 2001). Both political and economic institutions that were given the power to check presidential power 
could only watch as Estrada exercised his tremendous power over them. One key factor would have been his power of appointment. Estrada had sealed his impunity from particular acts as he appointed his own "henchmen" in government. With such collusion, accountability from state institutions could not be realized unless appointed individuals breathe life into them. Furthermore, given the network of complicity and patronage that crosses between independent and co-equal branches, the operation of the principle of checks and balances was virtually impaired. This facilitated Estrada's survival or escape from any form of accountability, even when being plainly answerable - explaining or justifying his decisions or behavior - to the public (Arugay, 2004a).

Estrada has apparently mastered the craft of impunity during the first part of his administration. As the mechanisms instituted to ensure that Estrada would not go beyond the limits of the authority vested in him by the people proved to be incapacitated, unconventional avenues and unorthodox means emerged to fill this vacuum. Estrada's perceived deficit in competence, his supposed penchant for cronyism, and the blatant allegations of corruption fed into the non-state sphere of the Philippine polity.

Exercising Societal Accountability: Strategies and Methods

Composed of a huge array of forces, the anti-Estrada campaign was a civil-society led, directed, and controlled initiative of various formations of social movements, NGOs, church and other faith-based organizations, professional associations, civic groups and others. There was the realization that it would take a tremendous amount of coalition-building and alliance-making in order to organize the campaign, achieve visibility nationwide, and succeed in exacting accountability from Estrada. In a way, this civil-society initiative to obtain accountability had no precedent in post-Marcos Philippine politics. Some observers noted that the conglomeration was an achievement in itself as odds of uniting was almost next to impossible, given their diverse nature, motivations, and interests. A momentary convergence on getting rid of Estrada forced even groups that were located at opposite ends of the ideological-political spectrum to unite (Carroll, 2001).

The anti-Estrada campaign relied on the use and interaction of a range of strategies and tactics with the objective of raising the issue of corruption against Estrada nationwide and intensifying the call either for his resignation, impeachment, or ouster (RIO) from office. Most of the time, they are coordinated but each group is also given free rein to contribute to the ends of the campaign.

Exposing Estrada: The Role of Media

The early role of media in the anti-Estrada campaign took the form of uncovering a "political scandal". Through what is called "watchdog" journalism (Markovits and Silverstein, 1998; Thompson, 2000), the different allegations of corruption against the former President were revealed to the public. It gave substance, voice, and visibility to the suspected corrupt practices of Estrada that was significant in convincing political actors (legislators and bureaucrats), other sectors of civil society, and the Filipino citizenry at large.

It was not difficult convincing the constituents of civil society and in the end, even the politicians and the public at large on the veracity of Estrada's corruption scandals. As early as July 2000, the highly reputable Philippine Center for Investigative Journalism (PCIJ), an independent, nonprofit media agency that specializes in investigative reporting since 1989, has produced several exposés that substantiated the allegations of corruption against the President. The reports that it was able to 
produce revealed that Estrada, with his relatives, owned multiple corporations not declared in his SAL. Others stories laid bare Estrada's questionable estate multiple mansions in very posh and exclusive villages in the country allegedly given to his mistresses.

The PCIJ was able to exercise societal accountability at both the non-institutional and institutional levels. On the one hand, it was able to impose "social sanctions" on Estrada through the exposition of the various anomalies and instances of corruption that directly involved the President. It severely damaged the reputation of Estrada being the "champion of the masses" and deliverer of the poor. It raised questions on the sincerity of Estrada's aspiration to alleviate poverty when he used government funds and money derived through illegal means to aggrandize himself, his family, and friends. On the other hand, the more important contribution of the PCIJ to societal accountability was its impact at the institutional level. In the end, three of the reports were cited in the historic impeachment complaint filed by the House of Representatives against Estrada. The PCIJ's contribution to societal accountability must be situated in twin contexts on media and democracy in the Philippines. In the first place, the organization's reputation for producing critical journalism and institutional integrity made it a credible vehicle for denouncing Estrada's corrupt acts. Moreover, its nature as an alternative media organization gave it further credence to investigate Estrada without prejudice. The PCIJ is distinct from mainstream media organizations which are very much contoured by commercial interests or dictates of market consumers. Therefore, the case of the exposés against Estrada clearly supports the argument that it is not just media per se that contributes to societal accountability but a critical type known as "watchdog" journalism - one that scrutinizes the activities and behavior of public officials guided by the protection and promotion of the public interest and the pursuit of transparency and accountability in governance.

In the end, the unraveling of the political scandal that involved the President attained high levels of reach and legitimacy that even political institutions such as congressional committees and the Ombudsman were activated to respond to the findings of the reports. From the perspective of civil society, the reports only validated their widely recognized perceptions, and galvanized them to coordinate efforts directed towards the President's accountability.

Activating Impeachment through Advocacy

Societal accountability claims that for initiatives of civil society and media to be formally recognized by state authorities, they must be anchored in juridical or legal processes. Patterned after the US model of presidential democracy, the Philippine political system provides that the only means to remove a president from office is through impeachment. While it was an option for civil society groups to disregard this constitutional process, as the political institutions assigned for this responsibility are captives of awesome presidential power, they still treaded the democratic route and gave a chance for political institutions to prove their efficacy. Thus, this legal strategy of impeaching Estrada best reflected the linkages between societal initiatives and the respect for the rule of law and constitutional democracy.

The main obstacle to the implementation of this strategy was the seeming difficulty of impeaching a public official. There exists the absence of a successful impeachment precedent of a president or any official for that matter in the country's political history. It was therefore unavoidable that there was skepticism with regard to the goal of the 
civil society actors, especially when they engaged the opposition politicians in Philippine Congress. Moreover, it was apparently an insurmountable task because the impeachment procedure has to be initiated in the lower chamber of Congress through the consent of more then one-third of its members. This was perceived as unlikely, given the dominance of Estrada's coalition. No sane and rational representative would risk alienating himself or herself by supporting the impeachment of the Chief Executive, especially when the next congressional elections were just months away.

However, a crucial political opportunity, to use a concept in social movements and contentious politics theories (Tarrow, 1994), emerged when there was a dramatic shifting in the balance of forces that inevitably exposed the President's vulnerability. This was caused by the damning testimony by an Estrada crony regarding the extent of the President's alleged corrupt acts. The exposition of Estrada's incriminating activities greatly corroborated the charges in the complaint that the civil society groups where initially preparing. It also became a catalyst for other civil society groups to join the initiative and to constitute themselves as a united front demanding Estrada's accountability. As impeachment is a political process that requires the support of a definite number of legislators, the resignation of the leader of the lower chamber and others from the ruling coalition shifted the tide against Estrada and made his impeachment possible. Even if there was glaring evidence that could impeach the President, the ultimate decision rested in the legislature who had the sole authority to activate the mechanism. What could be observed is that to achieve its objectives, the legal strategy depended not only on the initiatives of civil society but also on changes and dynamics within "political society".

The driving motivation for societal actors to pursue the President's impeachment despite the numerous obstacles they faced was adherence to the principles of democracy, particularly constitutionalism and the rule of law. It could be argued then that the legal strategy reflected the association between societal accountability and democratization. By becoming the initiators, advocates, and campaigners in the impeachment of Estrada, they were able to provide another angle in the highly politicized interplay between politicians. The active role of civil society prevented the demand for his accountability from becoming an alltraditional elite affair. It also refuted that it was all part of a conspiracy of the marginalized political opposition to sabotage Estrada and his administration. In the end, there was a semblance that it was a genuine, broad, and popular political movement to demand for his accountability.

\section{Mobilizing for Accountability}

While there were sporadic mobilizations exerted primarily by progressive civil society groups, the character and intensity of protest actions dramatically changed in the RIO campaign. Not only were they enjoined by a broad coalition of other forces, they were also conducted in a more organized manner with certain strategic objectives aimed at producing certain impacts but were all directed in exacting societal accountability. Civil society coalitions like the Kongreso $n g$ Mamamayang Pilipino II (The Congress of the Filipino People II) or Kompil II (Velasco, 2003) and the Estrada Resign Movement (ERM) used the mobilizational strategy through concerted and coordinated protest and mass actions. By reviving the so-called "parliament of the streets" and giving it new dimensions and peculiarities, the organized collective 
action was successful in its numerous objectives.

During the resignation phase of the campaign, the protest actions were aimed at sounding off "alarms" by pinpointing the issues against Estrada. These rallies reflected the intolerable problems of having a sitting president that had lost the moral credibility to govern. The protest actions had the objective of seeking Estrada's resignation as the most practical way of resolving in what was seen as a national crisis of governance. The rallies were centered in Metro Manila but had its counterparts across other urban centers of the country. They were successful in exacting preliminary social sanctions towards the President as they elevated the issues in the public agenda. While Estrada had categorically denied his involvement in the charges thrown against him, this did not ameliorate the severe damage that was inflicted on his reputation and political capital.

Estrada's counter-maneuvers to regain support for his administration stimulated the civil society coalitions to shift to another strategy and thereby change the nature and the goal of the mobilizations. With the impeachment process gaining ground in Congress, Kompil II and ERM focused their energies in becoming "societal watchdogs" of the historic trial that was intended not only to systematically present the evidence of Estrada's wrongdoings but to even give the President a fighting chance to defend himself. It was also a stark reminder to the political institutions that they, the people, were actively monitoring the procedure. Indeed, the daily vigils and monitoring of the proceedings illustrated this resolve to monitor the trial and keep it under the keen and watchful eye of civil society.

The mobilizations were further modified to its final form when the impeachment trial failed to exact accountability from Estrada. Exogenous developments beyond their control dramatically modified the political landscape and civil society organizations had no choice but to resort to mobilizations as the final form of collective action that could deliver the promise of accountability. Perhaps the final mobilizations that contributed to the ouster of Estrada could be interpreted as the venue for the public to participate in this process. As much as this was delegated to the political institutions of the country that should be representatives of the popular will, their failure had driven people to assume that task and confront the injustice that was inflicted because of the flagrant suppression of the truth by the loyal allies of the President.

The mobilizations not only intensified and heightened the consciousness of the issues of accountability against Estrada. They were also complemented by the power of media in magnifying the impacts of the mobilizations. The relentless coverage of all the mass actions in both print and broadcast media transmitted information and images of the vigilance of civil society to demand accountability from Estrada. The convergence of interests between civil society and mainstream media organizations was critical in being able to disseminate the frenzy of protest actions in the progression of the campaign to millions of Filipinos both at home and abroad, not to mention the global attention it was receiving from the international press. The series of collective action organized by the societal actors also ensured that the often ephemeral attention of the press would be maintained over an extended period of time requiring a great deal of organizational strength, cohesion, resources, and even ingenuity.

The Role of ICT: The Internet, the Television, and the Mobile Phone

To differentiate the case of the antiEstrada campaign from previous political mobilizations in the country, the role of information and communications 
technology must be highlighted. The case of the Internet-based initiative such as the eLagda.com was indicative of the power of technology as a means of political participation. What started as a reactive signature campaign aimed at pressuring Estrada to resign, the campaign of eLagda.com soon included active lobbying and participation into the protest actions in alliance with other civil society coalitions. What was novel was the inclusion of the politically apathetic middle class and the disempowered overseas Filipinos, working abroad which accounts for more than 10 percent of the population. Given the large number of Filipinos working and living outside the country, eLagda.com effectively provided them a channel to voice their claims and participate in the affairs of their country even if they were miles away. As they were disenfranchised politically, the campaign became their means of participation. In the end, eLagda.com campaign manifested that the Internet is not just a mechanism for information exchange regarding the issues confronted by Estrada but could be a potent weapon for societal accountability as it mobilized its constituencies separated by time, developed agendas for political participation and collective action, and generated public pressure on powerful politicians.

Another form of ICT was television considered as the main mode of mass media tapped into by Filipinos. As the country was about to undergo its first impeachment trial in history, networks grabbed the opportunity for it to broadcasted live into the television screens of Filipinos nationwide. It was seen as an exercise on political education, as ordinary citizens became acquainted with political and legal concepts and jargon (Enriquez, 2003). For almost a month, Filipino households were glued to their TV sets or radios watching or listening religiously to the trial proceedings, which on average lasted for six to seven hours of daily programming. The television allowed ordinary citizens to be jurors in their own right as events were unfolding before their very eyes in real time and not recorded beforehand. So much so that on the fateful day of 16 January 2001, almost 86 percent of Metro Manila residents and 60 percent nationwide watched the TV coverage (SWS, 2001). As a form of media, the television perfectly captured the perceived inclinations and the exhibition of partiality among pro-Estrada senatorjurors and the resulting preemption of the Presiding Officer's right to rule on the motion. This effectively culminated in public outrage that ended in a grand popular mobilization in January 2001.

The power of short messaging service (SMS) or "text" in Filipino parlance of the mobile phone was also heavily utilized. As an organizational device, emergency meetings among civil society groups could be announced and passed around leaders instantly. SMS also provided a cheap, effective, and efficient medium to diffuse information on protest actions and other similar activities. For the unorganized part of the citizenry, there was a periodic swapping of thousands of jokes and slogans about Estrada through their mobile handsets before and during the impeachment trial got under way (Rafael, 2003; Pertierra et al., 2002). Perhaps the mobilizing potential of the text service was exemplified in the spontaneous gathering that led to the Second People Power Revolt at the famous EDSA Shrine a few hours before the collapse of the impeachment trial. In the four-day grand mobilization, "texting" mainly provided the meeting schedules, locations, and even the proper attire for the protest actions.

Implications for Democratization in the Philippines 
The events that unfolded and the actions of civil society and media geared towards holding Joseph Estrada accountable can be considered as a watershed for democratization in the Philippines. However, it cannot be oversimplified to declaring that it was either a boon or bane to the country's pursuit for democratic consolidation. It has a Janus-faced character as it both manifested positive and negative indications of the state of Philippine democracy.

On a positive note, the ability and efficacy of civil society and the media to demand accountability from government is indeed a breakthrough in Philippine politics. They have reconceptualized the means and locus of accountability that was formerly restricted to elections and state institutions. Particularly in this case, societal actors had to come in since not much was to be expected from the government side to be able to elicit accountability. However, this paper will argue that there are still no alternatives for effective institutions of accountability. It must also be noted that all the activities of the societal actors of accountability would not be possible without the existence of a relatively open democratic space and the tradition of activism and participation in the Philippines. Both the constitution and other laws of the country have permitted the active role of civil society as a partner in governance. The so-called "NGO explosion" after 1986 has caused the proliferation of civil society organizations of all types and kinds increasing the density of the "non-profit" sector. Furthermore, the Philippines has relatively made great improvements in its observance and promotion of certain civil and political rights - particularly those of association and expression.

In this case, the PCIJ would not have produced its investigative reports without free access to public documents and the free atmosphere for media to operate in. Kompil II would not have been able to file the impeachment case if there was no precedent for citizen claims or suits, ERM would not have organized all those mobilizations without the observance of the right to assemble and the expression of dissent toward government, and finally eLagda.com would not have had the mandate for a signature campaign without the e-commerce Law and the recall mechanism for elected officials. In essence, the societal actors that were identified in this paper operated within the legitimate and democratic sphere and have assumed themselves as the legitimate claimants of the rights of the Filipino citizenry. Thus, in order for societal accountability to even commence, certain structural conditions would have to exist.

The other side of the coin seems to suggest that Philippine democracy remains uninstitutionalized, hollow, and muddled. The breakdown of the constitutional process of impeachment was the culminating indicator of the "accountability deficit" of the Philippine political system. As the main mechanism to be able to hold the most powerful politician in the land accountable, it was not insulated enough from the pressures of clientelism and partisan loyalty devoid of the public interest. According to a wellknown authority on Philippine politics, the turn of the events that unfolded in January 2001 speaks of the weakness of Philippine political institutions. Up to half of the senators appear to have been for sale. Furthermore, the very weak nature of Philippine political parties facilitated Estrada's fall as even the leading members of his coalition left as soon as his misgovernance was exposed (Landé, 2001).

Definitely, the accountability deficit should be a concern for the current regime as a perception of the prevalence of corruption and other particularistic acts would definitely cause undue duress on the legitimacy and stability of the country. 
Indicators coming from both domestic and foreign surveys on the ability of the government to impose accountability have not been that desirable. For example, the country's scores in the Transparency International's (TI) Corruption Perceptions Index have been decreasing for the past three years (Arugay, 2004b).

This case has exemplified the ability of Philippine civil society to act as a guardian of democracy and its ability to rise in indignation to abuses of political power. However, this must be treated with guarded optimism as most of the civil society leaders were appointed to key government posts in the current Macapagal-Arroyo administration. Civil society's ability to produce able, publicspirited, and honest governance will be tested.

Furthermore, this paper argues that one positive implication is that the government, civil society, and the Filipino people at large have taken the issue of corruption with more significance. While it will remain a disease that will plague the country, an awareness of corruption and its repercussions seems to be emerging. This can impinge upon the existing "culture of impunity" upon corrupt officials who have mastered the art of surviving accountability.

The challenge for Philippine democracy is how to address the accountability deficit on the country's institutions and at the same time balancing it with the emergence of societal accountability carried by a relatively powerful civil society. The case of the RIO campaign against Estrada cannot be totally categorized as a successful case of societal accountability given that its outcome must ultimately result in the strengthening of the vertical and horizontal institutions of accountability.

As far as holding Estrada accountable goes, the process is ongoing as his trial for the crime of plunder has yet to be finalized. Some of the societal actors have created special bodies to be "watchdogs" in the plunder trial, indicating that civil society will continue to keep a observant eye in this struggle. In the meantime, accountability in the Philippines remains to be a work-in-progress and thus a future challenge for the present and future administrations.

This paper is an abridged version of the author's masteral thesis submitted last June 2004. The author is grateful to the organizers of the $3^{\text {rd }}$ International Convention of Asia Scholars (ICAS) and the $1^{\text {st }}$ Congress of the Asian Political and International Studies Association (APISA) for the opportunity to present earlier versions of this paper as a graduate student. Also, the author is thankful to Carolina Hernandez, Nathan Quimpo, Enrique Peruzzotti, Catalina Smulovitz, Djorina Velasco, and Jason Brownlee for reading this paper.

\section{References}

Abueva, Jose V. 2001. A Crisis of Political Leadership: From "Electoral Democracy" to "Substantive Democracy". In Between Fires: Fifteen Perspectives on the Estrada Crisis edited by Amando Doronila, 78-97. Pasig City: Anvil Publishing.

Arugay, Aries A. 2004a. The Politics of Societal Accountability in the Philippines: A Study of the Issues, Actors, and Strategies in the Resignation, Impeachment, and Ouster (RIO) Campaign against Former President Joseph Ejercito Estrada. Unpublished MA Thesis, University of the Philippines. 
Arugay, Aries A. 2004b. The Accountability Deficit in the Philippines: Challenges and Prospects for Democratic Consolidation. Paper presented at the Regional Conference of the Philippine Political Science Association (PPSA), Manila, 23-24 October.

Burton, Sandra. 2001. "People Power Redux," Time. 29 January.

Carroll, John J. 2001. Civil Society, the Churches, and the Ouster of Erap. In Between Fires: Fifteen Perspectives on the Estrada Crisis edited by Amando Doronila, 236-251. Pasig City: Anvil Publishing.

De Dios, Emmanuel S. 2001. Corruption and the Fall. In Between Fires: Fifteen Perspectives on the Estrada Crisis edited by Amando Doronila, 43-61. Pasig City: Anvil Publishing.

Diamond, Larry. 2000. Thinking About Hybrid Regimes. Journal of Democracy 13(3):21-35.

Doronila, Amando. 2001. The Fall of Joseph Estrada: The Inside Story. Pasig City: Anvil Publishing.

Enriquez, Elizabeth L. 2003. Media As Site of Social Struggle: The Role of Radio and Television in the EDSA Revolts of 1986 and 2001. Paper presented at the 3rd National Philippine Studies Conference, 5-6 December.

Huntington, Samuel P. 1991. The Third Wave: Democratization in the Late Twentieth Century. Norman: University of Oklahoma Press.

Hutchcroft, Paul. 1998. Booty Capitalism: The Politics of Banking in the Philippines. Ithaca: Cornell University Press.

Landé, Carl H. 2001. The Return of 'People Power' in the Philippines, Journal of Democracy 12(2):88-102.

Laquian, Aprodicio and Eleanor Laquian. 2002. The Erap Tragedy: Tales from the Snake Pit. Pasig City: Anvil Publishing.

Luz, Guillermo M. People Power 2: A Business Perspective. In Between Fires: Fifteen Perspectives on the Estrada Crisis edited by Amando Doronila, 264-278. Pasig City: Anvil Publishing.

Manin, Bernard, Adam Przeworski, and Susan C. Stokes. 1999. Introduction. In Democracy, Accountability, and Representation, edited by Adam Przeworski, Susan C. Stokes, and Bernard Manin, 1-26. Cambridge: Cambridge University Press.

Markovits, Andrei and Mark Silverstein, eds. 1998. The Politics of Scandal: Power and Process in Liberal Democracies. London: Holmes and Meier 
March, James G. and Johan P. Olsen. 1995. Democratic Governance. New York: The Free Press.

O’Donnell, Guillermo. 1999. Horizontal Accountability in New Democracies. In The Self-Restraining State: Power and Accountability in New Democracies, edited by Andreas Schedler, Larry Diamond, and Marc F. Plattner, 29-51. Baltimore: Johns Hopkins University Press.

O’Donnell, Guillermo. 1994. Delegative Democracy. Journal of Democracy 5(1):55-69.

Pascual, Clarence and Joseph Lim. 2001. Corruption and Weak Markets: The BW Resources Stock Market Scam. Public Policy 5(1):109-129.

Pertierra, Raul, Eduargo F. Ugarte, Alicia Pinggol, Joel Hernandez, and Nikos Lexis Dacanay. 2002. Txt-ing Selves: Cellphones and Philippine Modernity. Manila: De La Salle University Press.

Peruzzotti, Enrique and Catalina Smulovitz. 2005. Societal Accountability: The Other Side of Control. In Enforcing the Rule of Law: The Politics of Societal Accountability in Latin America, edited by Enrique Peruzzotti and Catalina Smulovitz, 1-32. Pittsburgh: University of Pittsburgh Press.

Peruzzotti, Enrique and Catalina Smulovitz. 2002. Civil Society, the Media, and Internet as Tools for Creating Accountability to Poor and Disadvantaged Groups. Occasional Paper No. 13. New York: United Nations Human Development Report Office.

Putzel, James. 2001. A Muddled Democracy - People Power Philippine Style. Working Paper. London: Development Studies Institute.

Rafael, Vicente L. 2003. The Cell Phone and the Crowd: Messianic Politics in the Contemporary Philippines. Public Culture 15(3):399-245.

Rosenau, James N. 1990. Turbulence in World Politics: A Theory of Continuity and Change. Princeton: Princeton University Press.

Schedler, Andreas. 1999. Conceptualizing Accountability. In The Self-Restraining State: Power and Accountability in New Democracies, edited by Andreas Schedler, Larry Diamond, and Marc F. Plattner, 66-92. Baltimore: Johns Hopkins University Press.

Smulovitz, Catalina and Enrique Peruzzotti. 2000. Societal Accountability in Latin America. Journal of Democracy 11(4):147-158.

Social Weather Stations (SWS). 2001. From Juetenggate to People Power 2: The SWS Surveys of Public Opinion. Presentation made at the Philippine Social Science Center, Quezon City, 16 February. 
Spaeth, Anthony. 2001. Oops, We Did It Again. Time. 29 January.

Stokes, Susan C. 1999. What Do Policy Switches Tell Us About Democracy? In Democracy, Accountability, and Representation, edited by Adam Przeworski, Susan C. Stokes, and Bernard Manin, 98-130. Cambridge: Cambridge University Press.

Tarrow, Sidney. 1994. Power in Movement: Social Movements, Collective Action, and Politics. Cambridge: Cambridge University Press.

Thompson, John B. 2000. Political Scandal: Power and Visibility in the Media Age. Cambridge: Polity Press.

Velasco, Djorina R. 2003. Civil Society's Engagements and Disengagements: The Case of Kompil II. Unpublished M.A. thesis, Ateneo de Manila University.

Zakaria, Fareed. 1997. The Rise of Illiberal Democracy. Foreign Affairs 7(6):22-43. 